\title{
PERBANDINGAN KONSEP KEPRIBADIAN MENURUT BARAT DAN ISLAM
}

\author{
AGUS SILAHUDIN \\ Badan Wakaf Al-Qur'an \\ aseanvisiator@gmail.com
}

\begin{abstract}
Personality is something that attracts the attention of many parties. Many theories that try to give some concepts and definitions related to the human personality with different points of view. Western psychologists try to provide a definition of personality that is psychological based on the word person, but until now the personality psychologists themselves still do not agree on what the definition of personality actually is. While in Islam, the concept of personality has been thoroughly discussed in various Islamic literature. The Apostle as an example for Muslims has applied the concept of personality and actions and behavior. Thus, the concept of personality according to Islam, that Islamic personality is defined as "a unified integration of the workings of aqliyah and nafsiyah based on Islamic faith which gives birth to actions". Human personality is not shaped and influenced by body shape, face and other accessories. Human personality is formed by aqliyah and nafsiyah.
\end{abstract}

Keywords: Kepribadian barat, Kepribadian Islam

\section{PENDAHULUAN}

Kepribadian merupakan sesuatu yang menarik perhatian banyak pihak, banyak teori-teori yang mencoba memberikan beberapa pengertian terkait makna kepribadian tersebut dengan sudut pandang yang berbeda-beda. Para ahli psikologi barat berusaha memberi pengertian kepribadian yang bersifat psikologis berdasarkan kata persona, namun sampai sekarang para ahli psikologi kepribadian sendiri masih belum sepakat mengenai apa sebenarnya definisi kepribadian, meskipun banyak definisi yang telah ditawarkan selama ini (Abdul Mujib, 1999). Terkait dengan konsep kepribadian yang diuraikan oleh para psikolog barat, Abdul Mujib menganggap perlu adanya usaha untuk membangun makna kepribadian dalam kontek psikologi Islam (Abdul Mujib, 1999). Dari sisi pengembangan ilmu, upaya ini 
Agus Silahudin; Perbandingan Konsep Kepribadian Menurut Barat Dan Islam.

sebagai pembanding atau bahkan membantah terhadap teori-teori kepribadian yang dibangun dari paradigma psikologi barat. Karena masyarakat muslim tentunya tidak cocok menggunakan teori-teori kepribadian yang bercorak psikologi barat atau sekuler (pemisahan agama dari kehidupan).

Masyarakat muslim lebih tepat menggunakan teori kepribadian yang berbasis keislaman, karena teori ini dapat mengakomodasi seluruh perilaku dan perbuatannya (Abdul Mujib, 1999). Namun, konsep dan metode pembentukan kepribadian islami belum banyak dikembangkan oleh para ilmuan muslim itu sendiri, sehingga hal ini mempengaruhi sulitnya penerapan kepribadian islami dan metode pembentukannya. Dengan demikian, sangat penting sekali untuk mengkaji dan menganalisis konsep dan teori tentang kepribadian islami dalam pandangan ilmuan muslim.

\section{KONSEP KEPRIBADIAN DALAM PANDANGAN ILMUAN BARAT}

Para ahli psikologi barat berusaha memberi pengertian kepribadian yang bersifat psikologis berdasar kata persona, namun sampai sekarang para ahli psikologi kepribadian sendiri masih belum sepakat mengenai apa sebenarnya definisi kepribadian, meskipun banyak definisi yang ditawarkan selama ini. Oleh karena itu menurut Allport yang dikutip oleh Abdul mujib, salah satu tugas para ahli adalah menyeleksi pengertian psikologis yang paling sesuai.

\section{Definisi Secara Etimologis}

Secara etimologis, kata "kepribadian" berasal dari bahasa Latin yaitu "persona" yang berarti "topeng" yakni topeng yang dipakai oleh aktor drama dan sandiwara yang mengacu pada sebuah pertunjukkan sandiwara yang menggunakan topeng oleh aktoraktor Roman dalam drama yunani. Para aktor ini menggunakan topeng untuk menonjolkan peran atau berpenampilan tiruan. Kemudian dalam beberapa bahasa kepribadian disebut dengan istilah personality (Inggris), personalidad (Spanyol), dan personalichkeit (Jerman).

\section{Definisi Secara Terminologis}

\section{Secara terminologis,} kepribadian telah banyak didefinisikan dengan berbagai ragam makna dan pendekatan. Kebaragaman makna ini pada dasarnya disebabkan oleh beberapa faktor, diantaranya adalah faktor perbedaan dalam hal landasan keilmuan dan sudut pandang yang digunakan. Berikut ini adalah definisi kepribadian secara terminologis dalam pandangan ilmuan psikolog barat.

a. Allport, dalam Sumadi Suryabrata, mendefinisikan kepribadian adalah organisasi dinamis dalam individu sebagai sistem psikofisis yang menentukan caranya yang khas dalam menyesuaikan diri terhadap lingkungan (Sumardi. S, 1993).

b. Sigmund Freud, dalam Abdul Mujib, mendefinisikan kepribadian adalah integrasi dari id, ego dan super ego (Abdul Mujib, 2007).

c. Murray, dalam Adz-Dzakiey, mendefinisikan kepribadian adalah kesinambungan tingkah laku lahiriyah dari lahir sampai mati (Adz-dzakiey, 2006).

d. W. Stern, dalam Abdul Aziz Ahyadi, mendefinisikan kepribadian adalah aktualisasi 
dan realisasi dari hal-hal yang sejak semula telah terkandung dalam jiwa seseorang (Ahyadi. AA, 1987).

e. Carl Gustav Jung dalam Abdul Mujib, mendefinisikan, kepribadian adalah integrasi dari ego, ketidaksadaran pribadi dan ketidaksadaran kolektif yang melahirkan tingkah laku (Abdul Mujib, 1999).

f. George Herbert dalam Lawrence A. Perwin, mendefinisikan kepribadian ialah tingkah laku pada manusia yang berkembang melalui perkembangan diri. Perkembangan kepribadian dalam diri seseorang telah berlangsung seumur hidup, menurutnya manusia akan berkembang dengan secara bertahap melalui interaksi dengan anggota masyarakat (Lawrence A.P, 2015).

g. Eysenck dalam Lawrence A. Perwin, mendefinisikan kepribadian sebagai keseluruhan pola perilaku, baik yang aktual maupun yang potensial dari organisme yang ditentukan oleh pembawaan dan lingkungan (Abdul Mujib, 1999).

Demikianlah beberapa definisi kepribadian secara terminologis menurut ilmuan barat. Dalam hal ini para ilmuan barat berbeda-beda dalam mendefinisikan kepribadian.

\section{Analisis \\ Kepribadian \\ Pandangan IImuan Barat \\ Dari seluruh definisi teori} kepribadian psikologi barat yang telah dikemukakan di atas, terdapat berbedaan pandangan ilmuan psikologi barat dalam mendefinisikan kepribadian. Namun dari keseluruhan definisi tersebut dapat diambil kesimpulan menurut ilmuan psikologi barat kepribadian dipengaruhi dan dibentuk oleh lingkungan dimana manusia berinteraksi dan pengalaman kehidupan yang dialami. Dengan demikian, ilmuan psikologi barat berpandangan bahwa yang membentuk atau yang mempengaruhi kepribadian manusia adalah lingkungan tempat tinggal dan pengalaman kehidupannya.

Pandangan ilmuan psikologi barat tentang kepribadian manusia tersebut dibangun dari pengetahuanpengetahuan yang diperoleh melalui pengamatan dan penggalian secara lahiriyah semata, yaitu dengan cara pengkajian yang berulang-ulang terhadap sejumlah orang yang berbeda-beda dalam kondisi dan situasi yang berbeda-beda pula. Sehingga menimbulkan sebuah kesimpulan bahwa kepribadian manusia dibentuk dan dipengaruhi oleh lingkungan dan pengalaman kehidupannya. Kemudian hasil dari pengamatan tersebut disimpulkan dan dijadikan sebuah teori yang digunakan untuk mewakili seluruh umat manusia. Dalam hal ini, menurut pandangan penulis tidak tepat. Karena kondisi manusia di suatu wilayah berbeda dengan kondisi manusia di wilayah yang lain. Sehingga pengatahuan yang dijadikan landasan oleh ilmuan psikologi barat terhadap manusia tersebut berupa dugaan yang berpotensi ke arah salah, disamping dibangun di atas landasan yang simpang siur. Akhirnya kekeliruan pandangan mengenai kepribadian manusia tersebut membawa konsekuensi pada kekeliruan terhadap konsep kepribdian manusia dan pembentukan kepribadian manusia. Demikianlah konsep teori 
Agus Silahudin; Perbandingan Konsep Kepribadian Menurut Barat Dan Islam.

kepribadian menurut imuan psikologi barat yang menurut penulis masih perlu dikaji ulang kebenarannya.

\section{UNSUR-UNSUR PEMBENTUK KEPRIBADIAN MENURUT BARAT}

Menurut pandangan ilmuan barat, dalam psikologi kepribadian barat modern, pembahasan mengenai unsur-unsur kepribadian manusia dibicarakan oleh beberapa tokoh, sebagai berikut:

1. Menurut Sigmund Freud, dalam Sumadi Suryabrata, unsur kepribadian terdiri atas tiga sistem atau aspek (Sumardi. S, 1993), yaitu :

a. Id (das es) adalah sistem kepribadian biologis yang asli, berisikan sesuatu yang telah ada sejak lahir. Berorientasi kepada kesenangan yang merupakan sumber insting kehidupan atau dorongan biologis (makan, minum, tidur, dsb.) prinsip kesenangannya merujuk pada pencapaian kepuasan yang segera dari dorongan biologis tersebut.

b. Ego (das Ich) merupakan aksekutif atau manajer dari kepribadian yang membuat keputusan tentang instinginsting mana yang akan dipuaskan dan bagaimana caranya; atau sebagai sistem kepribadian yang terorganisasi, rasional dan berorientasi kepada prinsip realitas. Peran utamanya sebagai mediator yang menjembatani antara id dengan kondisi dunia luar.

c. Super Ego (das uber ich) merupakan komponen moral kepribadian yang terkait dengan standar atau norma masyarakat mengenai baikburuk dan benar-salah. Super ego bekerja untuk mengontrol diri sendiri, mencapai kesempurnaan kepribadian (Sumardi. S, 1993).

Unsur-unsur kepribadian ini membentuk kepribadian pada diri seseorang sehingga melahirkan tingkahlaku atau perbuatan, ketika ketiga unsur ini berjalan sesuai dengan fungsinya masing-masing. Yaitu ketika id membutuhkan pemenuhan kemudian ego mempertimbangkan apakah dipenuhi atau tidak sesuai dengan pertimbangan dari super ego berdasarkan norma-norma di suatu lingkungan atau masyarakat. Keputusan akhir dari pertimbangan super ego inilah yang menentukan suatu perbuatan pada diri seseorang, sehingga terbentuklah kepribadian pada diri seseorang sesuai dengan tingkah laku atau perbuatan-perbuatan yang dilakukannya. Inilah proses pembentukan kepribadian berdasarkan id, ego dan super ego menurut Sigmund Freud. Dengan demikian, pembentukan kepribadian menurut Sigmund Freud hanya terfokus kepada kebutuhan alami manusia, kemudaian insting yang berfungsi mempertimbangkan apakah dipenuhi atau tidak sesuai dengan norma-norma lingkungan.

2. Menurut Carl Rogers dalam Lawrence A. Perwin, 2015, unsur kepribadian terdiri dari dua aspek, yaitu:

a. Diri (The Self). Merupakan konsep diri, yang merepresentasikan pola persepsi yang terorganisasi dan konsisten. Individu memahami objek dan 
pengalaman eksternal dan memberikan makna kepada diri sendiri sehingga membentuk konsep diri. Walaupun diri selalu berubah, akan tetapi diri selalu mempertahankan kualitas yang telah berpola dan terintegrasi sehingga menjadi karateristik seseorang, maka diri adalah unsur kepribadian.

b. Diri Ideal (Ideal Self). Diri ideal adalah konsep diri yang paling diinginkan oleh individual. Konsep tersebut mencakup persepsi dan makna yang secara potensial relevan terhadap diri dan amat penting bagi individu tersebut. Dengan demikian, Rogers menyadari bahwa pandangan manusia akan diri sendiri mengandung dua komponen yang aling berlawanan yaitu, diri saat ini dan diri yang dilihat sebagai wujud ideal diri dimasa datang.

Dari kedua teori yang telah dikemukakan diatas, dapat ditarik kesimpulan. Pertama, menurut teori psikoanalitis Freud, aspek-aspek yang membentuk dan mempengaruhi kepribadian manusia terdiri dari dorongan biologis bawah sadar dan perkembangan karakter di usia awal sesuai pengalaman kehidupannya berdasarkan lingkungan tempat tinggal yang terdiri dari id, ego dan super ego. Dengan demikian, menurut teori ini kepribadian manusia dibentuk oleh pengalamannya dimasa lalu yang kemudian menjadi karakter pada diri manusia yang kemudian membentuk unsur dalam diri manusia berupa id, ego dan super ego yang selanjutnya ketiga unsur inilah sebagai komponen pembentuk kepribadian manusia.
Sebaliknya, menurut pendekatan fenomenologis Rogers, aspek-aspek kepribadian manusia terdiri dari persepsi sadar, perasaan berkaitan dengan interaksi sosial kemudian dijadikan dasar untuk memaknai diri sendiri, sehingga membentuk konsep diri. Kemudian terbentuklah pribadi saat ini. Kemudian keinginan pribadi masa datang yang ideal sesuai dengan pandangannya terhadap lingkungan. Berdasarkan hal ini, motif aktualisasi diri dan proses perubahan terhadap diri (the self) adalah dalam rangka meraih diri ideal (ideal self). Dengan demikian, menurut teori ini kepribadian manusia dibentuk oleh lingkungan tempat tinggal, hasil dari interaksi-intaraksi dengan lingkungannya-lah yang mempengaruhi dan membentuk kepribadian pada seseorang yang selanjutnya menjadi konsep diri sesuai dengan keinginannya.

Inilah unsur-unsur pembentuk kepribadian dalam pandangan ilmuan barat. Dalam hal ini, ilmuan barat lebih menekankan lingkungan hidup sebagai unsur dari luar diri manusia yang lebih dominan dalam pembentukan kepribadian manusia. Ilmuan barat mengeyampingkan peran ilmu pengetahuan dan agama dalam pembentukan kepribadian. Hal ini tentunya sesuai paradigma yang mereka yakini yakni sekularisme.

\section{KONSEP KEPRIBADIAN ISLAMI DALAM PANDANGAN ILMUAN MUSLIM}

Agar pembahasan ini tersistematis dan mudah difahami, maka definisi kepribadian secara etimologis, terminologis, dan unsur kepribadian serta definisi yang diadopsi dalam penelitian ini perlu 
Agus Silahudin; Perbandingan Konsep Kepribadian Menurut Barat Dan Islam.

dibahas secara detail sebagai berikut:

\section{Definisi Kepribadian Menurut Ilmuan Muslim}

Mendefinisikan kepribadian adalah merupakan usaha untuk mendeskripsikan manusia sebagai objeknya, melalui sifat-sifatnya, dari aspek komprehensif (jâmi') dan protektifnya (mâni'). Adapun yang dimaksud dengan definisi harus bersifat komprehensif (jâmi') dan protektif (mâni') adalah definisi itu harus menyeluruh meliputi seluruh aspek yang dideskripsikan, dan memproteksi sifat-sifat di luar substansi yang dideskripsikan (Abdurrahman. $\mathrm{H}, 2007$ ).

a. Definisi Kepribadian secara Etimologis

Secara etimologis, kata "kepribadian" lebih dikenal dengan term al-Syakhshiyah yang berasal dari kata "syâkhsh" yang berarti "pribadi". Kata itu kemudian diberi yâ' an-nisbah sehingga menjadi kata benda buatan "syakhshiyah" yang berarti "kepribadian". Dalam kamus bahasa Arab modern, istilah syakhsiyah digunakan untuk maksud kepribadian (Abdul Mujib, 2017). Namun, dalam literatur keislaman pada khazanah klasik abad pertengahan, kata syakhshiyah (sebagai padanan dari kepribadian) kurang begitu dikenal, pada masa itu para tokoh ilmuan muslim lebih mengenal term akhlak daripada term syakhshiyah (Abdul Mujib, 2017).

Sedangkan dalam literatur keislaman modern, term syakhshiyah telah banyak digunakan untuk menggambarkan dan menilai kepribadian individu. Sebutan syakhshiyah al-muslim memiliki arti kepribadian orang
Islam. Pergeseran makna ini menunjukkan bahwa term syakhshiyah telah menjadi kesepakatan umum untuk dijadikan sebagai padanan dari kepribadian (personality) (Abdul Mujib, 2017).

b. Definisi Kepribadian secara Terminologi

Definisi kepribadian secara terminologi menurut Ilmuan Muslim adalah sebagai berikut:

1) Ibnu Qayyim al-Jauziyah dalam Yadi Purwanto, mendefinisikan kepribadian adalah hasil kerja bareng dan dinamika integrasi dari unsur kepribadian yang terdiri dari potensi nafsiyah (jasad dan naluri) dan potensi akal dalam penggunaannya (Purwanto. Y, 2007).

2) Abdul Mujib mendefinisikan kepribadian adalah satu kesatuan integrasi dari sistem kalbu, akal dan hawa nafsu, yang menimbulkan tingkah laku (Abdul Mujib, 2017).

3) Hafidz Abdurrahman mendefinisikan kepribadian adalah akumulasi dari cara berfikir seseorang dalam menghukumi realitas, serta kecendrungan nafsiyah terhadap realitas tersebut (Abdurrahman. H, 2007).

Dari berbagai definisi kepribadian yang telah dikemukakan oleh ilmuan muslim di atas, terdapat perbedaan pandangan dalam mendefinisikan kepribadian manusia. Hal ini disebabkan karena dalam mendefinisikan kepribadian manusia menggunakan sudut pandang yang berbeda-beda sesuai dengan pemahaman dan keilmuan yang dimiliki oleh masing-masing ilmuan muslim. Sehingga lahirlah 
definisi kepribadian yang berbeda satu sama lain diantara ilmuan muslim.

Berdasarkan pemaparan di atas, dalam rangka menemukan titik temu tentang definisi kepribadian manusia menurut ilmuan muslim, maka penulis menggabungkan definisi dari pandangan ilmuan muslim tersebut sehingga dapat mewakili dari seluruh definisi yang telah dikemukakan oleh ilmuan muslim. Dengan demikian, dari pandangan ilmuan muslim tentang kepribadian manusia tersebut, maka kepribadian dapat penulis definisikan sebagai "satu kesatuan integrasi dari cara kerja aqliyah (Abdurrahman. $\mathrm{H}$, 2007) dan nafsiyah (Purwanto. $Y$, 2007) berdasarkan akidah tertentu yang diyakini kemudian melahirkan perbuatan". Definisi inilah yang memenuhi syarat jâmi' (komprehensif) dan mâni' (protektif), sehingga dapat mewakili seluruh definisi kepribadian dalam pandangan ilmuan muslim.

\section{Definisi Kepribadian Islami}

Sebagaimana yang telah dikemukakan di atas, dari berbagai definisi kepribadian secara etimologis dan terminologis menurut ilmuan muslim, kemudian penulis mendefinisikan kepribadian sebagai "satu kesatuan integrasi dari cara kerja aqliyah dan nafsiyah berdasarkan akidah tertentu yang diyakini kemudian melahirkan perbuatan".

Sedangkan kata Islam berasal dari bahasa Arab, "aslama" artinya tunduk dan patuh (Purwanto. Y, 2007). Kemudian secara terminologis umum, definisi Islam menurut Imam al-Bajuri dalam anNawawi, adalah:

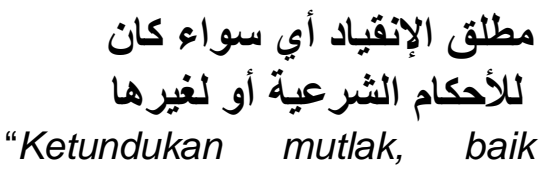

"Ketundukan mutlak, baik terhadap hukum syariah atau hukum selain syariah" (Muhamamd AnNawawi, tt).

Adapun secara terminologis syara', menurut Imam al-Jurjani, Islam adalah:

$$
\text { الخضوع والانقياد، لما أخبر به الله عليه وسلم }
$$

"Tunduk dan patuh terhadap informasi yang dibawa Rasulullah Saw. (Al-Jurjani)

Sedangkan Imam al-Bajuri dalam Al-Jurjani, menjelaskan:

$$
\text { الإستياد للأحكام الثرعية وقيل العمل انتهى }
$$

"Islam adalah, tunduk/patuh terhadap hukum-hukum syariah, dengan kata lain Islam adalah amal yang terakhir (yang dilakukan sampai sempurna semua rukunnya)" (Al-Jurjani).

Kemudian Syaikh Taqiyuddin an-Nabhani, definisi Islam adalah:

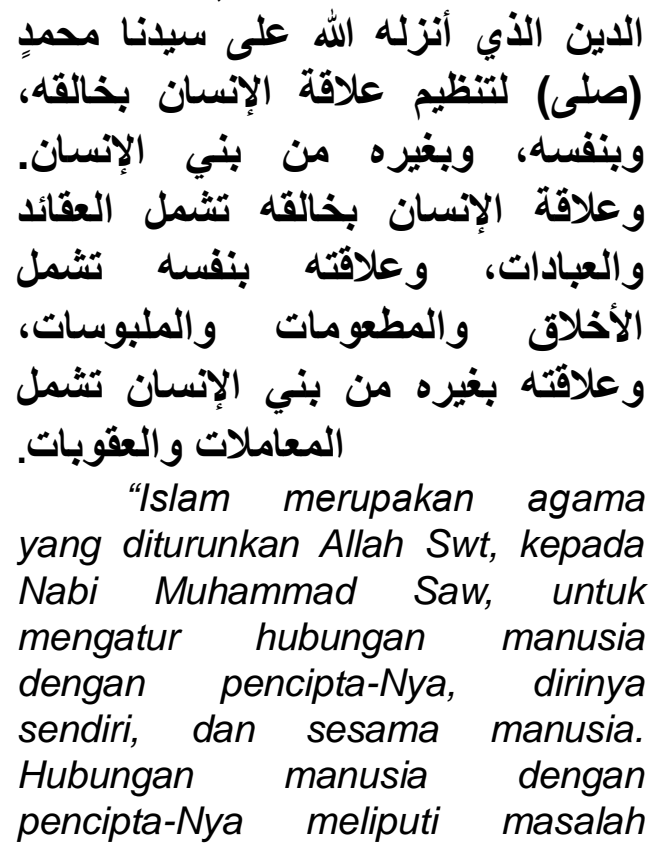


Agus Silahudin; Perbandingan Konsep Kepribadian Menurut Barat Dan Islam.

aqidah (keyakinan/ keimanan) dan ibadah. Hubungan manusia dengan dirinya sendiri meliputi akhlaq, makanan-minuman dan pakaian yang dikenakannya. Adapaun hubungan manusia dengan sesamanya meliputi mu'amalah dan uqubat (hukum pidana / sanks)" (AnNabhani, 2001).

Definisi ini diambil dari beberapa nas, baik al-Qur'an maupun hadits. Definisi itu sendiri merupakan deskripsi realitas yang bersifat jâmi' (komprehensif) dan mâni' (protektif), Adapun yang dimaksud dengan definisi harus bersifat komprehensif (jâmi') dan protektif (mâni') adalah definisi itu harus menyeluruh meliputi seluruh aspek yang dideskripsikan, dan memproteksi sifat-sifat di luar substansi yang dideskripsikan. Artinya, definisi itu harus menyeluruh meliputi seluruh aspek yang dideskripsikan, dan memproteksi sifat-sifat di luar substansi yang dideskripsikan. Inilah gambaran mengenai definisi yang benar (Abdurrahman. H, 2007). Dalam hal ini, Syaikh Taqiyuddin an-Nabhani telah mendefinisikan Islam dengan definisi yang lebih lengkap, jelas dan lebih mudah dipahami dari beberapa definisi ulama sebelumnya, ruang lingkupnya meliputi semua aspek kehidupan. Karena Islam adalah sistem aturan atau syariah Islam yang merupakan hukum yang meliputi semua aspek kehidupan manusia, yang semuanya telah dijelaskan oleh sumber utamanya, yaitu al-Qur'an dan as-Sunnah secara umum dan global. Hal tersebut sesuai dengan firman Allah Swt, dalam al-Qur'an surat an-Nahl ayat 89 :

$$
\text { "Dan kami turunkan }
$$

kepadamu Al Kitab (Al Quran) untuk menjelaskan segala sesuatu dan petunjuk serta rahmat dan kabar gembira bagi orang-orang yang berserah diri" (TQS. An-Nahl : 89)

Ayat ini menjelaskan bahwa diturunkannya al-Qur'an berfungsi sebagai penjelas, petunjuk dan pedoman bagi kehidupan manusia secara keseluruhan. Oleh karena itu sudah semestinya kita menjalankan dan menta'ati ajaran yang terkandung didalam al-Qur'an secara menyeluruh.

Berdasarkan penjelasan di atas, kepribadian islami didefinisikan sebagai, "satu kesatuan integrasi dari cara kerja aqliyah dan nafsiyah berdasarkan akidah Islam yang melahirkan perbuatan". Dalam kata lain, kepribadian islami adalah, terintegrasinya antara aqliyah dan nafsiyah yang melahirkan seluruh perbuatan manusia yang menjadikan akidah Islam sebagai landasannya. Demikianlah, definisi tentang kepribadian Islami, definisi ini dapat digunakan sebagai konsep atau teori kepribadian Islam yang ideal, yang seharusnya dimiliki oleh umat Islam.

\section{Unsur-Unsur Pembentuk Kepribadian Menurut IImuan Muslim}

Dalam pandangan Islam, penentuan unsur kepribadian manusia tidak dapat terlepas dari pembahasan substansi manusia, sebab dengan pembahasan substansi tersebut dapat diketahui hakikat dan dinamika prosesnya. Unsur kepribadian manusia yang dimaksud di sini adalah aspek-aspek atau elemen-elemen yang terdapat pada diri manusia yang karena aspek-aspek ini kepribadian terbentuk (Abdul Mujib, 2017).

Ibnu Qoyyum al-Jauziyah dalam Yadi Purwanto, menjelaskan 
unsur kepribadian manusia terdiri dari potensi nafsiyah (jasad dan naluri) dan potensi akal (Purwanto, 2007). Sedangkan menurut Abdul Mujib unsur kepribadian manusia terdiri dari kalbu, akal dan hawa nafsu (Abdul Mujib, 2017). Kemudian menurut Hafidz Abdurrahman unsur kepribadian manusia terdiri dari aqliyah dan nafsiyah (Abdurrahman. $\mathrm{H}, 2007$ ). Dengan demikian, dapat disimpulkan menurut pandangan ilmuan muslim unsur kepribadian manusia terdiri dari jasad, akal, kalbu dan nafsiyah (nafsu). Selanjutnya unsur-unsur pembentuk kepribadian tersebut dijelaskan sebagai berikut.

a. Jasad

Jasad meliputi tingkah laku luar manusia yang mudah nampak dan ketahuan dari luar, misalnya cara-cara berbuat dan cara-cara berbicara

(Abdurrahman. H, 2007). Aspek jasad ini adalah merupakan aspek biologis sebagai pelaksana tingkah laku perbuatan manusia (Ahyadi, 1995). Dengan demikian jasad adalah merupakan organ tubuh manusia yang secara fisik terlihat oleh kasat mata. Adapun fungsi jasad dalam proses pembentukan kepribadian adalah sebagai pelaksana dari unsurunsur lainnya yang berupa tingkah laku atau perbuatan.

b. Akal

Lafadz akal berasal dari bahasa Arab; dari lafadz aql. Secara istilah akal adalah kekuatan yang dapat digunakan untuk menghukumi sesuatu. Atau dengan ungkapan yang lebih tegas, akal adalah kemampuan untuk menghukumi fakta/realitas tertentu, baik yang berkaitan dengan perbuatan maupun benda yang dibangun berdasarkan pandangan hidup tertentu (Ahyadi, 1995). Dengan demikian, akal adalah merupakan potensi yang dimiliki oleh manusia yang berfungsi untuk berfikir atau menghukumi sebuah fakta/realitas yang terindera, yang mana akal adalah merupakan khasiyat dari otak manusia. Dalam proses pembentukan kepribadian manusia, akal berfungsi sebagai pembuat keputusan terhadap fakta/realitas dan sebagai penentu pelaksanaan perbuatan, apakah perbuatan tersebut dilakukan atau tidak.

c. Kalbu

Kalbu merupakan materi organik yang memiliki sistem kognisi yang berdaya emosi. Kalbu terdiri dari dua aspek, yaitu kalbu jasmani dan kalbu ruhani. Kalbu jasmani adalah daging sanubari yang berbentuk seperti jantung pisang yang terletak di dalam dada sebelah kiri. Sedangkan kalbu ruhani adalah sesuatu yang bersifat halus, ruhani yang berhubungan dengan kalbu jasmani. Kalbu ruhani ini memiliki insting yang disebut dengan nur ilahi (cahaya ketuhanan) dan al-bashirah albatinah (mata batin) yang memancarkan keimanan dan keyakinan (Hartati, 2004). Dalam proses pembentukan kepribadian fungsi kalbu adalah melahirkan sebuah keyakinan terhadap fakta/realitas atau perbuatan tertentu apakah dilakukan atau tidak.

d. Nafsiyah (nafsu)

Nafsiyah berasal dari lafadz nafs yang ditambah dengan huruf yâ' an-nisbah. Makna nafsiyah 
Agus Silahudin; Perbandingan Konsep Kepribadian Menurut Barat Dan Islam.

secara etimologis adalah sesuatu yang berkaitan dengan nafsu dan yang sejenis dengannya, atau yang berhubungan dengan sifatsifat nafsu. Sedangkan nafsu itu sendiri maknanya sama dengan hawâ, yaitu kecenderungan atau dorongan yang ada dalam diri manusia untuk melakukan sesuatu, baik karena dorongan kebutuhan jasmani maupun naluri. Karena itu, nafsiyah tidak akan terlepas dari makna nafsu itu sendiri, yang bisa didefinisikan dengan cara (metode) yang digunakan oleh seseorang untuk memenuhi dorongan (dawâfi) yang lahir dari kebutuhan jasmani dan naluri berdasarkan standar landasan tertentu (Abdurrahman. $\mathrm{H}$, 2007). Dalam proses pembentukan kepribadian pada seseorang fungsi nafsu adalah yang melahirkan berbagai keinginan dan mendorong serta menunutut pemenuhan.

Berdasarkan penjelasan di atas, kepribadian terbentuk ketika dorongan dari nafsu ini muncul kemudian dikaitkan dengan akal yang akan menghukumi dorongan tersebut, lahirlah sebuah keputusan dan diyakini oleh kalbu, kemudian dilakukan oleh jasad. Inilah proses terbentuknya kepribadian manusia menurut ilmuan muslim.

\section{KONSEP KEPRIBADIAN ISLAMI MENURUT ISLAM}

Menurut Syaikh Taqiyuddin AnNabhani, kepribadian manusia tidak ada kaitannya dengan bentuk tubuh, wajah, keserasian fisik dan hal lain sejenisnya. Manusia memiliki keistimewaan disebabkan akalnya, sementara baik atau buruknya kepribadian manusia ditunjukkan oleh perbuatannya (An-Nabhani,
2003). Dengan demikian kepribadian manusia dinilai dari perbuatanperbuatan yang dilakukannya, sehingga setiap perbuatan yang dilakukan seseorang menjadi identitas kepribadiannya.

Menurut Syaikh Taqiyuddin an-Nabhani, Perbuatan adalah aktifitas yang dilakukan manusia dalam rangka memenuhi kebutuhan jasmani dan nalurinya. Perbuatan manusia terkait erat dengan mafahimnya serta tidak bisa dipisahkan (An-Nabhani, 2003). Sedangkan mafahim adalah pemahaman terhadap fakta/realitas berdasarkan landasan tertentu yang diyakini sebagai informasi yang tersimpan di dalam otak. Pemahaman terbentuk pada seseorang ketika memusatnya antara fakta dengan informasi atau sebaliknya (An-Nabhani, 2003). Inilah fungsi akal dalam diri manusia, yakni menghukumi fakta berdasarkan landasan tertentu yang diyakini. Aktifitas ini disebut dengan pola berpikir atau aqliyah, sedangkan hasil dari aqliyah ini disebut dengan mafahim. Adapun aktifitas pemenuhan kebutuhan jasmani dan naluri berdasarkan mafahim yang dimiliki oleh seseorang disebut dengan pola sikap atau nafsiyah, sedangkan hasil dari nafsiyah ini disebut dengan perbuatan. Berdasarkan hal ini, mafahim dan perbuatan merupakan inti dan dasar dari kepribadian seseorang (An-Nabhani, 2003). Berdasarkan penjelasan di atas, kepribadian dapat didefinisikan sebagai, "satu kesatuan integrasi dari cara kerja aqliyah dan nafsiyah berdasarkan akidah tertentu yang diyakini kemudian melahirkan perbuatan". Definisi ini bersifat umum untuk seluruh definisi 
Al-Fikra: Jurnal IImiah Keislaman, Vol. 17, No. 2, Juli - Desember, 2018 (249 278)

kepribadian manusia. Kemudian konsep kepribadian menurut Syaikh digambarkan dalam sebuah skema Taqiyuddin an-Nabhani ini dapat berikut ini:

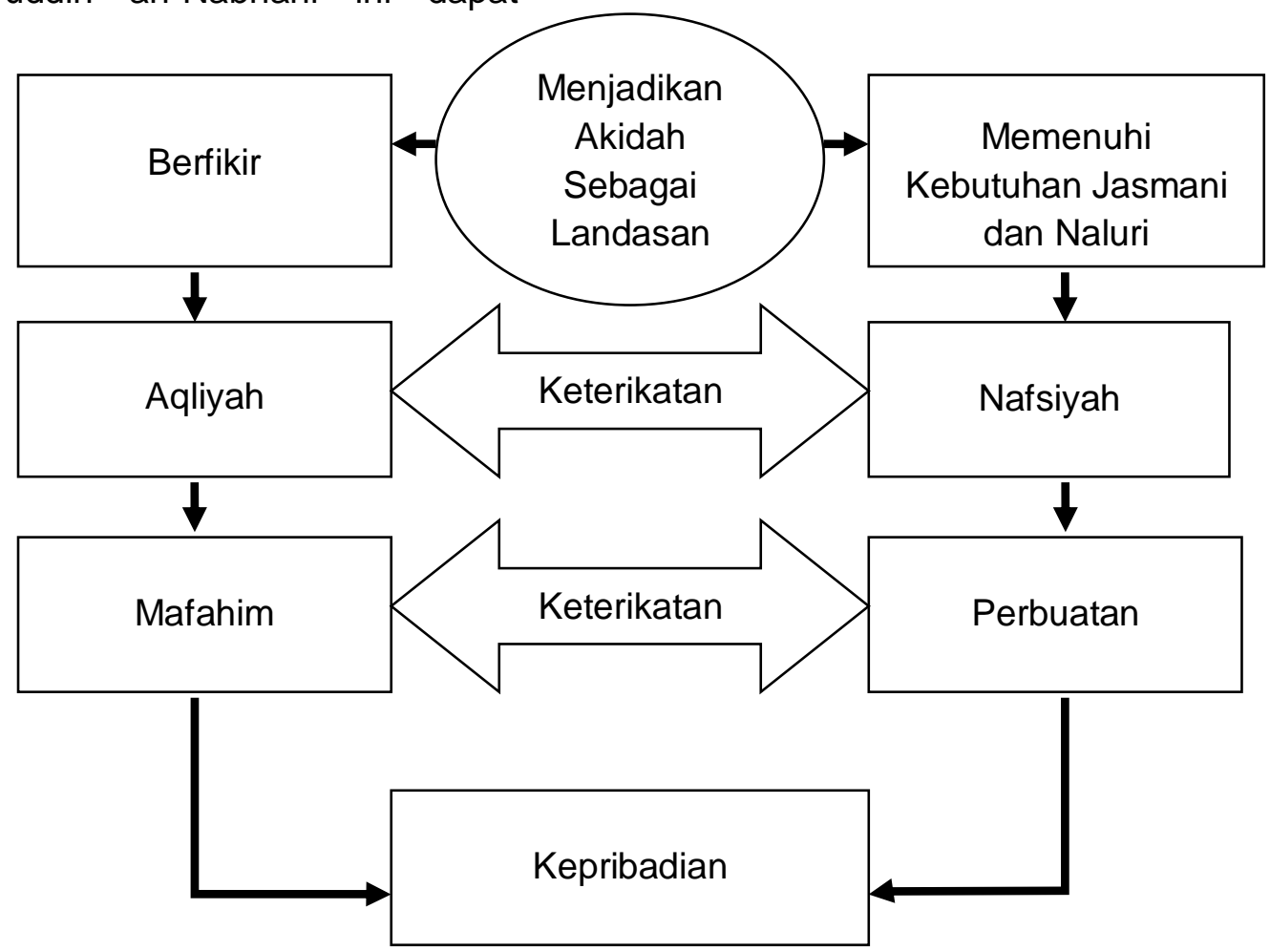

Gambar 1. Skema konsep kepribadian secara umum

Perbuatan yang dilakukan oleh manusia yang merupakan makna dari kepribadiannya adalah meliputi semua perbuatan zahir maupun perbuatan batin. Perbuatan zahir adalah perbuatan yang tampak yang dilakukan oleh fisik manusia seperti kaki untuk melangkah, tangan untuk memegang, mata untuk memandang, hidung untuk mencium, telinga untuk mendengar, mulut untuk berbicara dan perbuatan lainnya yang tampak secara fisik.

Sedangkan perbuatan batin adalah perbuatan yang tidak tampak, seperti perbuatan akal dalam memikirkan sesuatu, perbuatan hati yaitu, yakin, ikhlas, iri, dengki, hasad, prasangka buruk atau baik dan lain sebagainya. Semua perbuatan ini muncul sesuai dengan pemahaman yang dimiliki oleh seseorang. Dan dari seluruh perbuatan inilah yang menjadi nilai kepribadian seseorang. Sedangkan semua perbuatan tadi lahir dari proses kerja antara aqliyah dan nafsiyah. Dengan demikian, berdasarkan aqliyah dan nafsiyah inilah terbentuknya kepribadian. Ketika landasan yang digunakan aqliyah sama dengan landasan yang digunakan nafsiyah atau sebaliknya, maka terbentuklah kepribadian yang khas. Namun ketika landasan yang digunakan oleh aqliyah berbeda dengan landasan yang digunakan nafsiyah atau sebaliknya, maka terbentuklah kepribadian yang kacau. Berdasarkan hal ini, dalam membentuk kepribadian islami, maka harus mewujudkan satu landasan bagi aqliyah dan nafsiyahnya sehingga menjadi 
Agus Silahudin; Perbandingan Konsep Kepribadian Menurut Barat Dan Islam.

aqliyah Islam dan nafsiyah Islam. Dengan aqliyah dan nafsiyah inilah kepribadian islami terbentuk. Inilah konsep kepribadian secara umum menurut pandangan Syaikh Taqiyuddin an-Nabhani.

\section{Konsep Kepribadian Islami}

Menurut Syaikh Taqiyuddin anNabhani, Islam telah memberikan solusi terhadap manusia dalam mewujudkan kepribadian islami, yaitu dengan menjadikan akidah Islam sebagai landasan berfikir, yang diatas landasan tersebut dibangun seluruh pemikirannya serta dibentuk pemahamannya dalam memberikan solusi atas perbuatanperbuatan manusia yang timbul dari kebutuhan jasmani dan nalurinya dengan hukum-hukum syara' yang terpancar dari akidah Islam. Dengan demikian setiap orang yang berpikir berdasarkan akidah Islam dan hawa nafsunya dikembalikan kepada akidah Islam maka seseorang tersebut memiliki kepribadian islami (An-Nabhani, 2003).

Kepribadian islami terwujud pada diri seseorang ketika aqliyah dan nafsiyahnya menyatu dengan Islam, dan tidak cukup hanya dengan aqliyahnya saja yang islami, di mana misalnya seseorang bisa mengeluarkan keputusan hukum tentang benda dan perbuatan sesuai hukum-hukum syara', sehingga orang tersebut mampu menggali hukum, mengetahui halal dan haram. Semuanya itu belum cukup, kecuali setelah nafsiyahnya juga menjadi nafsiyah Islam, sehingga bisa memenuhi tuntutan kebutuhan jasmani dan nalurinya dengan landasan Islam. Sehingga orang tersebut mengerjakan shalat, puasa, zakat, haji, serta melaksanakan yang halal dan menjauhi yang haram. Demikian juga tidak cukup jika seseorang hanya memiliki nafsiyah Islam, sementara aqliyahnya tidak. Akibatnya, bisa jadi beribadah kepada Allah dengan kebodohan. Misalnya, berpuasa pada hari yang diharamkan; shalat pada waktu yang dimakruhkan, dan bermuamalah dan bersedekah dengan riba, dengan anggapan bisa mendekatkan diri kepada Allah, namun justru telah berbuat dosa. Dengan demikian kepribadian islami akan terwujud pada diri seseorang ketika memiliki aqliyah Islam dan nafsiyah Islam. Yakni seseorang yang mempelajari hukum-hukum syara, bukan sekadar untuk diketahui, tetapi untuk diterapkan dalam segala urusannya, baik dengan Penciptanya, dengan dirinya sendiri, maupun dengan sesamanya, sesuai dengan akidah Islam. Jika aqliyah dan nafsiyahnya telah terikat dengan Islam, berarti seseorang tersebut telah memiliki kepribadian islami. Berdasarkan hal ini, ketika akidah Islam yang dijadikan satusatunya tolak ukur umum terhadap seluruh pemikiran dalam menghukumi fakta, maka terbangunlah pemahaman islami yaitu aqliyah Islam. Dan ketika akidah Islam yang dijadikan satusatunya tolak ukur umum dalam pemenuhan dorongan kebutuhan jasmani dan nalurinya secara praktis dan riil, maka terbangunlah pola sikap islami yaitu nafsiyah Islam (AnNabhani, 2003). Dengan demikian, ketika seluruh perbuatan seseorang dibangun berdasarkan aqliyah Islam dan nafsiyah Islam maka terwujudlah kepribadian islami, yaitu kepribadian yang memiliki ciri khas Islam. Kepribadian islami pada diri seseorang dapat dilihat dari perbuatan-perbuatannya dan 
Al-Fikra: Jurnal IImiah Keislaman, Vol. 17, No. 2, Juli - Desember, 2018 (249278)

pemikiran-pemikirannya yang senantiasa terikat dengan akidah Islam.

Berdasarkan penjelasan di atas, kepribadian islami dapat didefinisikan sebagai, "satu kesatuan integrasi dari cara kerja aqliyah dan nafsiyah berlandaskan akidah Islam yang melahirkan perbuatan". Inilah definisi dan konsep kepribadian islami menurut pandangan Syaikh Taqiyuddin an-Nabhani. Kemudian konsep kepribadian islami dapat digambarkan dalam skema berikut ini:

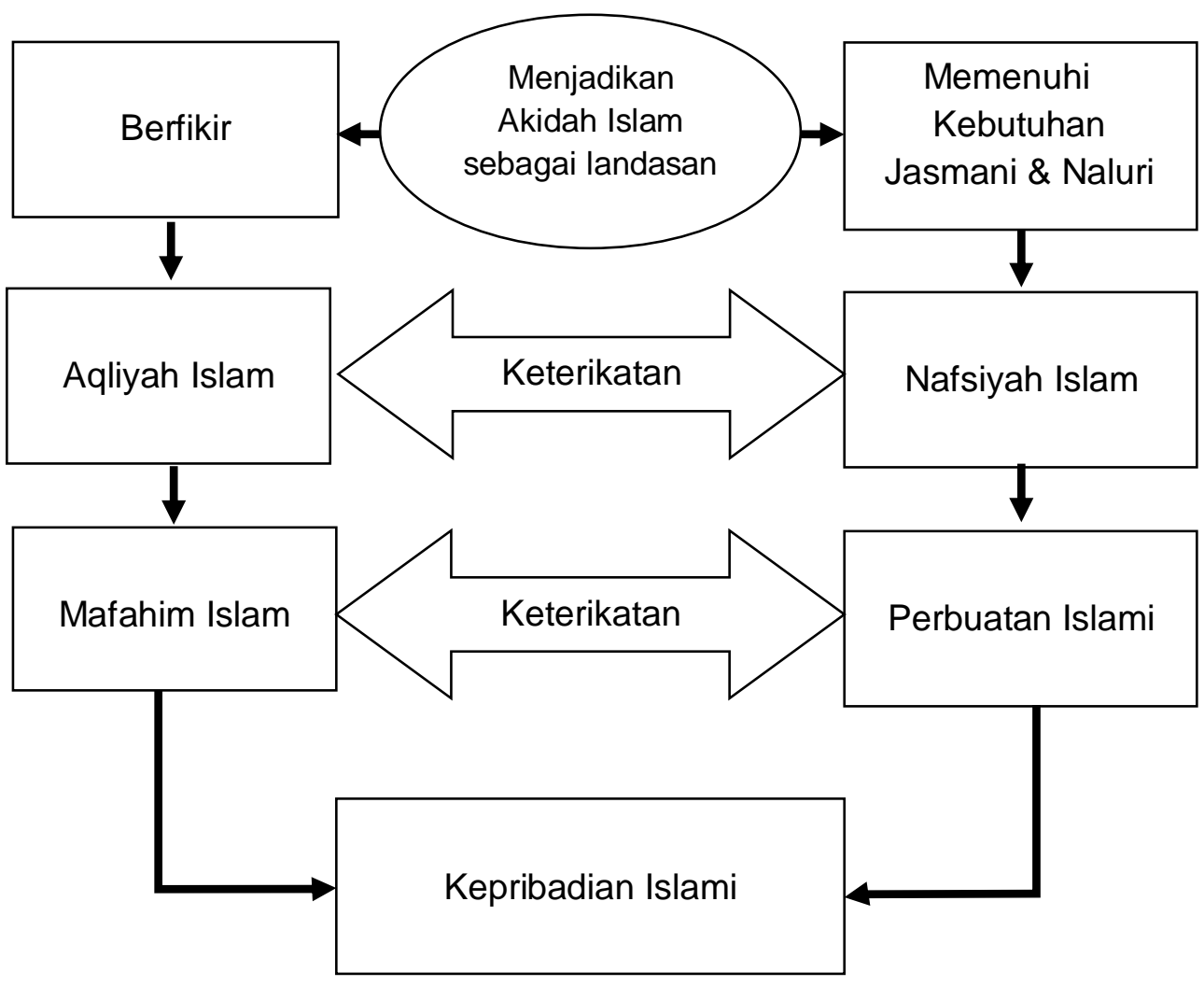

Gambar. 2. Skema Konsep Kepribadian Islami

Pandangan Syaikh Taqiyuddin an-Nabhani terhadap konsep kepribadian islami tersebut, menurut penulis sesuai dengan apa yang telah dijelaskan dalam al-Qur'an dan hadits. Sebagaimana firman Allah Swt: "Sesungguhnya tentang penciptaan langit dan bumi, serta perubahan siang dan malam itu terdapat tanda-tanda kebesaran Allah bagi orang-orang yang menipunyai akal. Yaitu, orang-orang yang senantiasa mengingat Allah ketika berdiri, duduk dan terbaring serta berfikir mengenai penciptaan langit dan bumi (seraya menyatakan) : "Tuhanku, tidakkah sia-sia Engkau ciptakan semua ini. Maha Suci Engkau, maka selamatkanlah kami dari azab neraka." (TQS. Ali-Imran:190-191).

Firman Allah di atas menunjukkan bahwa kedudukan manusia sebagai makhluk yang mulia karena akalnya, yaitu ketika akal yang diberikan oleh Allah 
Agus Silahudin; Perbandingan Konsep Kepribadian Menurut Barat Dan Islam.

digunakan dengan benar sesuai dengan akidah Islam dan senantiasa terikat dan tunduk terhadap Allah Swt. Dengan demikian, manusia bisa menjadi mulia ketika menggunakan akalnya sesuai dengan ketentuan akidah Islam. Namun sebaliknya ketika manusia tidak menggunakan akalnya dengan benar sesuai akidah Islam, maka manusia akan menjadi hina. Sebagaimana dijelaskan dalam alQur'an surat Al-a'raf ayat : 179, sebagai berikut :

"Kami telah menjadikan untuk isi neraka Jahanam, kebanyakan dari manusia dan jin. Mereka mempunyai akal, tetapi tidak digunakan untuk berfikir. Mereka mempunyai mata, tetapi tidak digunakan untuk melihat. Mereka mempunyai telinga, tetapi tidak digunakan untuk mendengar. Mereka itu seperti hewan, bahkan lebih hina lagi." (TQS. AI-A'raf: 179).

$$
\text { Hal ini dikarenakan }
$$

keistimewaan manusia dari makhluk lainnya terletak pada akal dan perbuatannya. Dengan akal manusia bisa membedakan mana yang baik dan mana yang buruk, mana perintah Allah dan mana larangan Allah Swt, serta bisa membedakan antara perbuatan yang baik dan perbuatan yang buruk sesuai hukum syara'. Dengan demikian, akal dan perbuatan manusialah yang menentukan kepribadian seseorang apakah termasuk kepribadian Islami atau bukan. Terkait hal ini Rasulullah Saw, bersabda:

ان الله لا ينظر الى صوركم وأموالكم ولكن إنما ينظر الى قلويكم وأعمالكم. "Sesungguhnya Allah tidak menilai wajah kamu serta harta kekayaan kamu, tetapi Dia hanya menilai hati dan amal perbuatan kamu" (H.R. Muslim dan Ibn Majah dari Abu Hurayrah) (As-Suyuthi, 1832).

Berdasarkan penjelasan di atas, kepribadian islami adalah merupakan perwujudan dari aqliyah Islam (pola fikir Islami) yakni seseorang yang menjadikan islam sebagai asasnya dalam berpikir dan nafsiyah Islam (pola sikap islami) yakni seseorang yang menjadikan Islam sebagai asasnya dalam berbuat. Pola pikir islami pada seseorang ditunjukkan dengan sikap, pandangan atau pemikiran yang ada pada dirinya dalam menyikapi berbagai realitas dan pemikiran tertentu. Sedangkan pola sikap islami pada seseorang ditunjukkan dengan perbuatanperbuatan nyata yang dilakukan seseorang dalam rangka memenuhi berbagai kebutuhan hidupnya (kebutuhan jasmani maupun nalurinya).

Walhasil, aqliyah (pola pikir) dan nafsiyah (pola sikap) inilah yang menentukan corak kepribadian seseorang. Ketika aqidah Islam yang dijadikan satu-satunya landasan dalam berpikir dan bersikap, maka terbentuklah kepribadian islami. Berdasarkan hal ini, landasan dari kepribadian islami adalah aqidah Islam. Islam memerintahkan kepada setiap pribadi muslim untuk senantiasa melaksanakan semua perbuatan yang wajib dan meninggalkan semua perbuatan yang haram. Islam juga memerintahkan untuk menolak setiap kecenderungan yang bertentangan dengan Islam. Hal ini dilakukan dalam rangka untuk menjaga dan meningkatkan kepribadian islami menuju martabat yang lebih tinggi lagi mulia. Setiap pribadi muslim yang memiliki akal sehat pasti bisa memiliki kepribadian 
yang islami, termasuk didalamnya orang awam yang bukan berpendidikan tinggi maupun orangorang yang berpendidikan. Ketika seseorang mengkaitkan setiap tingkah lakunya dengan Islam maupun hanya menjalankan perkara-perkara wajib dan meninggalkan perkara-perkara haram saja, mereka tergolong berkepribadian islami, sekalipun setiap orang memiliki kepribadian yang berbeda-beda kekuatannya. Karena yang terpenting adalah selama seseorang menjadikan Islam sebagai asas bagi pemikiran (aqliyah) dan kecenderungan (nafsiyah) nya, maka dia memiliki kepribadian islami. Namun, orang yang berkepribadian islami bukanlah seperti malaikat, sebuah kekeliruan bagi orang yang beranggapan bahwa seseorang yang memiliki kepribadian islami sama seperti malaikat. Karena kita tidak akan pernah bisa mencari malaikat ditengah-tengah manusia.

Islam diturunkan kedunia untuk diterapkan secara nyata dan Islam itu riil adanya. Islam memberikan solusi secara praktis dan penerapannya tidak sulit sehingga bisa di jangkau oleh semua manusia selemah apapun pemikirannya dan sekuat apapun gharizah dan kebutuhan jasmaninya. Semua manusia pasti bisa menerapkan Islam pada dirinya dengan mudah dan gampang asalkan memahami dan menyakini aqidah Islam. Karena hanya dengan menjadikan akidah Islam sebagai tolok ukur mafahim dan kecenderungannya, kemudian berjalan sesuai dengan tolak ukur tersebut, maka seseorang dipastikan sudah berkepribadian islami. Setelah itu tidak ada lagi yang harus dilakukannya kecuali memperkuat kepribadiannya dengan tsaqafah Islam untuk mengembangkan aqliyahnya disertai dengan melakukan berbagai ketaatan untuk memperkuat nafsiyahnya.

Islam telah memberikan solusi atas segala pemikirannya dengan akidah. Islam menjadikan akidah sebagai kaedah berpikir (qa'idah al fikriyah) yang dibangun diatasnya seluruh pemikiran tentang kehidupan, sehingga mampu membedakan antara pemikiran yang benar dan yang salah tatkala pemikiran tersebut ditimbang menggunakan tolok ukur akidah Islam yang dianggapnya sebagai kaedah berpikir. Dengan demikian seseorang yang memahami aqidah Islam akan selamat dari kegoncangan berpikir, terhindar dari kesalahan dan pemikiran yang rusak, serta tetap benar pemikirannya dan selamat pemahamannya.

Islam juga mengendalikan kecenderungan manusia dengan hukum-hukum syara' dengan memberikan solusi yang benar atas setiap perbuatan yang muncul dari kebutuhan jasmani maupun nalurinya, Islam telah mengaturnya, bukan mengekangnya apalagi memusnahkannya, Islam telah menselaraskannya bukan mengumbar (tanpa kendali), Islam menawarkan solusi terhadap pemenuhan seluruh kebutuhannya secara teratur, yang membawa pada ketenteraman dan ketenangan. Karena itu seorang muslim yang memeluk akidah Islam melalui proses berpikir dan dalil, menerapkan Islam pada dirinya secara total, memahami hukumhukum Allah dengan pemahaman yang benar, maka seorang muslim memiliki kepribadian Islami yang 
Agus Silahudin; Perbandingan Konsep Kepribadian Menurut Barat Dan Islam.

berbeda dengan kepribadian lainnya, yaitu menjadikan aqidah Islam sebagai landasan dalam setiap berfikir (aqliyah) dan bersikap (nafsiyah).

Dengan ini akan melahirkan manusia yang mampu menggabungkan antara sifat kasih sayang dengan sifat tegas. Manusia yang bisa hidup apa adanya atau diselimuti dengan kemewahan dan tetap bertaqwa kepada Allah. Manusia yang mampu memahami kehidupan dengan pemahaman yang benar berdasarkan aqidah Islam. Manusia yang sanggup menguasai kehidupan dunia sesuai dengan haknya dan berupaya meraih kehidupan akhirat dengan amalnya. Manusia yang tidak dapat ditaklukkan oleh sifat penghamba dunia, tidak didominasi sikap fanatik buta terhadap agama dan tidak hidup menyengsarakan diri. Manusia yang menjadi orang yang mulia namun bersifat rendah hati. Manusia yang faham hukum-hukum syara' dan mengamalkannya serta menjauhi segala kemaksiatan.

Manusia yang sifatnya yang paling tinggi adalah sebagai hamba Allah, yang khusyu' dalam shalatnya, berpaling dari perkataan yang siasia, membayar zakat, dan menundukkan pandangannya, menjaga amanat-amanatnya, memenuhi kesepakatannya, menunaikan janji-janjinya dan berjihad di jalan Allah Swt. Itulah hakikat seorang muslim dan seorang mukmin yang memiliki kepribadian islami. Dan inilah kepribadian islami (syakhshiyah Islamiyah) yang dibentuk oleh aqidah Islam dan tsaqofah Islam, yang telah melahirkan manusia sebaik-baik ciptaan. Dengan demikian keterikatan terhadap hukum syara' adalah merupakan dasar dari kepribadian islami.

\section{Unsur-Unsur Pembentuk Kepribadian Islami}

Menurut Syaikh Taqiyuddin anNabhani, kepribadian setiap manusia terbentuk dari aqliyah dan nafsiyah. Sedangkan kepribadian islami dibentuk oleh aqliyah Islam dan nafsiyah Islam. Aqliyah Islam adalah berpikir berdasarkan Islam, yakni menjadikan akidah Islam sebagai satu-satunya tolak ukur umum terhadap seluruh pemikiran tentang kehidupan. Sehingga melahirkan pemahaman Islam. Sedangkan nafsiyah Islam adalah menjadikan seluruh kecenderungannya bertumpu pada akidah Islam, yakni menjadikan akidah Islam sebagai satu-satunya tolok ukur umum terhadap seluruh pemenuhan kebutuhan jasmani dan nalurinya. Sehingga melahirkan perbuatan yang islami, yakni perbuatan yang seantiasa terikat dengan akidah Islam. Menyatunya antara aqliyah Islam dan nafsiyah Islam inilah terbentuknya kepribadian islami, yakni selarasnya antara pemahaman dan perbuatan seseorang dengan akidah Islam. Terbentuknya kepribadian islami tersebut ialah ketika terjalinnya unsur-unsur pembentuk kepribadian islami pada diri seseorang, yakni unsur pembentuk aqliyah Islam dan nafsiyah Islam (An-Nabhani, 1973).

Menurut Syaikh Taqiyuddin anNabhani, terbentuk aqliyah pada diri seseorang melibatkan empat unsur, yaitu panca indera, fakta, otak dan informasi. Jalinan dari keempat unsur ini disebut dengan aktifitas akal, yakni ketika panca indera mengindra fakta, kemudian memindahkan kedalam otak, dan 
diproses oleh akal dengan mengkaitkan fakta tersebut dengan informasi yang tersimpan didalam otak untuk menghukumi atau dimaknai kemudian lahirlah sebuah kesimpulan atau pemahaman atas fakta tersebut. Apa yang telah dihasilkan oleh pemahaman dari aktifitas akal tadi akan menjadi penentu perbuatan manusia dalam memenuhi dorongan kebutuhan jasmani dan naluri serta terhadap fakta-fakta yang ditemuinya. Juga sebagai penentu corak kecendrungan manusia terhadap fakta-fakta yang ditemui berupa sikap menerima atau menolak dan perasaan tertentu sehingga melahirkan sebuah perbuatan. Ketika setiap dorongan kebutuhan jasmani dan naluri muncul kemudian seantiasa dikaitkan dengan mafahim yang diliki dan menjadikan mafahim sebagai dasar seseorang melakukan perbuatan, maka dengan ini terbentuklah nafsiyah. Berdasarkan aqliyah dan nafsiyah inilah terbentuknya kepribadian (AnNabhani, 1973).

Kemudian Syaikh Taqiyuddin an-Nabhani menjelaskan, meskipun aqliyah diciptakan bersama dengan manusia dan keberadaannya pasti ada dalam setiap diri manusia, akan tetapi pembentukan aqliyah terjadi melalui usaha manusia itu sendiri. Begitu pula dengan perbuatan, meskipun melekat pada diri manusia dan keberadaannya pasti ada pada setiap diri manusia, akan tetapi pembentukan nafsiyah terjadi melalui usaha manusia. Hal ini disebabkan, karena yang menjelaskan makna sebuah fakta/realita sehingga menjadi pemahaman adalah adanya landasan yang dijadikan sebagai tolok ukur untuk menghukumi fakta/realita tersebut ketika seseorang berpikir, dan yang menjelaskan dorongan kebutuhan jasmani dan naluri untuk dipenuhi sehingga menjadi perbuatan adalah gabungan yang terjadi antara dorongan kebutuhan jasmani dan naluri dengan pemahaman. Oleh karena itu, adanya landasan yang dijadikan sebagai tolok ukur untuk menghukumi fakta/realita ketika manusia berfikir, mempunyai pengaruh yang sangat besar dalam pembentukan aqliyah, nafsiyah dan kepribadian (An-Nabhani, 1973). Dengan demikian ketika ingin membentuk kepribadian islami pada seseorang, maka harus menjadikan akidah Islam sebagai landasan dalam berfikirnya sehingga terbentuk aqliyah Islam dan menjadikan akidah Islam sebagai landasan dalam memenuhi dorongan kebutuhan jasmani dan nalurinya sehingga terbentuk nafsiyah Islam. Terjalinnya antara aqliyah Islam dan nafsiyah Islam inilah yang membentuk kepribadian islami.

Berdasarkan penjelasan di atas, unsur-unsur pembentuk kepribadian islami pada diri seseorang terdiri dari unsur-unsur yang telah ada dalam diri manusia dan unsur-unsur dari luar diri manusia, sebagaimana dijelaskan berikut ini:

a. Unsur-Unsur Kepribadian dalam Diri Manusia

1) Panca Indera

Panca indera terdiri dari lima macam alat indera, yaitu indera penglihatan, pendengaran, perasa, penciuman dan indera peraba. Indera juga meliputi berbagai rasa yang timbul dari potensi kebutuhan jasmani dan dorongan naluri, seperti rasa lapar dan dahaga, maupun 
Agus Silahudin; Perbandingan Konsep Kepribadian Menurut Barat Dan Islam.

berbagai perasaan atau emosi seperti rasa gelisah, rasa haru, dan rasa tertarik pada lawan jenis (An-Nabhani, 2003). Dalam proses pembentukan kepribadian, panca indera berfungsi menyerap berbagai fakta/realita yang terindera kemudian dikirim kedalam otak, sebagai informasi bagi otak. Sekalipun ada banyak panca indera yang dimanfaatkan dalam penginderaan, akan tetapi penginderaan semata tidak akan dapat menjadi landasan bagi perbuatan manusia. Apapun upaya penginderaan yang dilakukan manusia, tidak lebih hanya akan menghasilkan suatu reaksi saja.

\section{2) Otak}

Otak manusia adalah tempat dimana indera menyampaikan informasi tentang fakta/realita yang terindera. Otak adalah tempat informasi tentang realitas itu disimpan, dan juga tempat dimana hasil penginderaan itu dikaitkan dengan informasi awal. Disamping itu otak juga mempunyai fungsi-fungsi yang lain, seperti menerima dan mengirim sinyal-sinyal dari otak ke sistem syaraf. Meskipun fungsi otak adalah menerima, memproses, dan menyimpan informasi, tetapi kita tidak dapat menyimpulkan bahwa otak adalah satu-satunya "organ berpikir" karena proses berpikir juga melibatkan organ-organ tubuh lainnya, terutama alat-alat indera lainnya (An-Nabhani, 1973). Otak manusia adalah sesuatu yang ada dalam tengkorak kepala. Benda ini dikelilingi dengan tiga lapis selaput yang dijaring dengan rajutan urat saraf yang jumlahnya tidak terhitung, kemudian saraf tersebut dihubungkan ke seluruh indera dan bagian tubuh manusia. Berat otak manusia dewasa mencapai 1200 gram. Otak tersebut menghabiskan 25\% oksigen yang diperoleh dari kedua paru-paru. Para saintis telah berkesimpulan melalui eksperimen yang dilakukan dengan menggunakan alat eletronik pengukur kerja otak, bahwa otak merupakan organ yang berfungsi untuk berfikir. Melalui alat tersebut dapat diketahui, bahwa ketika seseorang sedang berfikir, grafik yang tertulis pada alat tersebut akan naik. Sebagian saintis bahkan telah sampai pada kesimpulan, bahwa informasi yang dapat disimpan oleh otak manusia mencapai tidak kurang dari 90 juta informasi. Inilah keunikan otak manusia yang tidak dimiliki oleh otak hewan (Abdurrahman. H, 2007). Otak menerima sinyal dan informasi, memproses informasi tersebut dan kemudian memberikan respon terhadapnya. Respon yang dihasilkan oleh otak manusia terbagi menjadi dua macam, yang pertama respon naluriah yang semata-mata berlandaskan pada proses kerja otak dan yang kedua respon 'aqliyah, yang berdasarkan pada upaya merujuk kepada mafahim atau kaidah tertentu. Dalam proses pembentukan kepribadian fungsi otak adalah sebagai tempat untuk menyimpan berbagai informasi yang akan dijadikan landasan oleh akal dalam menghukumi fakta yang terindera.

3) Akal 
Kata "akal" berasal dari bahasa Arab: al-'aql. Arti lafadz tersebut sama dengan al-idrâk dan al-fikr. Ketiga lafadz tersebut maknanya sama. Dalam bahwa Arab, kata seperti ini disebut mutâradif atau sinonim. Akal merupakan khâshiyyât yang diberikan oleh Allah Swt kepada manusia, yang merupakan khâshiyyât otak manusia. Sebab otak manusia mempunyai keistimewaan untuk mengaitkan realitas yang diindera dengan informasi. Dengan demikian, akal adalah kekuatan untuk menghasilkan sebuah keputusan atau pemahaman tentang sesuatu.

Syaikh Taqiyuddin anNabhani mendefinisikan akal ('aql), pemikiran (fikr), adalah pemindahan penginderaan terhadap fakta melalui panca indera kedalam otak yang disertai adanya informasi-informasi terdahulu yang akan menghukumi atau menafsirkan fakta tersebut (An-Nabhani, 1973). Dengan demikian, akal dalam menghukumi sebuah fakta untuk melahirkan sebuah pemahaman membutuhkan informasi tentang fakta tersebut. Tanpa adanya informasi tentang fakta tersebut maka akal tidak akan mampu menghasilkan sebuah pemahaman. Karena aktifitas akal adalah menghukumi fakta sesuai informasi terhadap fakta tersebut yang tersimpan di dalam otak. Dengan ini akal membutuhkan unsur dari luar yang berupa informasi-informasi pengetahuan berupa akidah maupun tsaqofah atau juga disebut dengan ilmu. Dalam pembentukan kepribadian, fungsi akal adalah menghukumi fakta berdasarkan informasi yang tersimpan dalam otak kemudian lahirlah sebuah kesimpulan atau pemahaman yang akan dijadikan landasan dalam menghukumi fakta/raelitas yang terindera dan dalam memenuhi kebutuhan jasmani dan naluri.

4) Nafsiyah

Nafsiyah berasal dari lafadz nafs yang ditambah dengan huruf yâ' an-nisbah. Makna nafsiyah secara etimologis adalah sesuatu yang berkaitan dengan nafsu dan yang sejenis dengannya, atau yang berhubungan dengan sifatsifat nafsu (Abdurrahman. $\mathrm{H}$, 2007). Sedangkan nafsu itu sendiri maknanya sama dengan hawâ, yaitu kecenderungan atau dorongan yang ada dalam diri manusia untuk melakukan sesuatu, baik karena dorongan kebutuhan jasmani maupun naluri. Karena itu, nafsiyah tidak akan terlepas dari makna nafsu itu sendiri (An-Nabhani, 1973).

Sedangkan secara terminologi, Syaikh Taqiyuddin an-Nabhani, mendefinisikan nafsiyah adalah cara yang digunakan oleh manusia untuk memenuhi dorongan kebutuhan jasmani dan naluri. Nafsiyah adalah merupakan gabungan dari dorongan kebutuhan jasmani dan naluri dalam pemenuhannya yang terjalin dengan mafahim (AnNabhani, 2003). Berdasarkan hal ini, di dalam nafsiyah terdapat dorongan kebutuhan jasmani dan naluri yang merupakan hawa nafsu yang menuntut untuk dipenuhi. Kemudian berkenaan dengan kebutuhan jasmani dan naluri ini dijelaskan sebagai berikut:

a) Kebutuhan Jasmani. 
Agus Silahudin; Perbandingan Konsep Kepribadian Menurut Barat Dan Islam.

Menurut Syaikh Taqiyuddin an-Nabhani, kebutuhan jasmani adalah merupakan potensi kehidupan yang mendorong manusia untuk melakukan aktivitas-aktivitas tertentu, serta menuntut pemenuhan yang sifatnya harus. Artinya, jika kebutuhannya tidak terpenuhi, maka akan mengakibatkan kerusakan organ tubuh yang bisa menyebabkan kematian. Contohnya, lapar, haus dan buang hajat. Sehingga, apabila manusia tidak memenuhi kebutuhan perkara-perkara tersebut, maka dapat mengakibatkan kerusakan pada organ-organ tubuh manusia bahkan bisa mati (An-Nabhani, 2003). Potensi kebutuhan jasmani ini adalah merupakan dorongan mendasar (basic needs) yang bekerja menurut homeostasis jaringan tubuh (Abdurrahman. $\mathrm{H}$, 2007). Dengan demikian, kebutuhan jasmani ini merupakan kebutuhan organ tubuh yang berkaitan dengan kadar tertentu yang telah ditetapkan oleh Allah pada manusia. Jika kadarnya kurang atau melampaui batas, maka tubuh manusia akan mengalami gangguan. Dalam hal ini, Allah telah memberikan isyarat dalam firman-Nya :

"Dan di antara tanpa-tandaNya, (Dia ciptakan) tempat untuk tidur kamu di waktu malam dan siang." (TQS. Ar-Rûm : 23).

"Ini adalah manusia biasa, yang masih memerlukan makan, sama dengan apa yang kamu makan, dan minum sama dengan apa kamu minum". (TQS. AlMu'minûn: 33).

Pada kadar tertentu, kebutuhan jasmani ini wajib dipenuhi. Sebab jika tidak dipenuhi akan menimbulkan kerusakan dan kematian. Dengan demikian, kebutuhan jasmani merupakan kebutuhan dasar manusia yang wajib dipenuhi. Hal ini telah Allah jelaskan dalam firman-Nya :

"Apakah mereka tidak memperhatikan, bahwa sesungguhnya Kami telah menjadikan malam supaya mereka beristirahat padanya dan siang yang menerangi? Sesungguhnya pada yang demikian itu terdapat tanda-tanda (kekuasaan Allah) bagi orangorang yang beriman". (TQS. AnNaml: 86).

Disamping itu, kebutuhan jasmani adalah kebutuhan yang lahir dari dalam tubuh manusia. Kebutuhan jasmani ini merupakan dorongan mendasar pada manusia, sebagai contohnya adalah:

I. Ketika tubuh manusia kekurangan air, maka kerja organ tubuhnya akan mengalami gangguan yang kemudian akan menyebabkan penyakit. Penyakit ginjal adalah contoh penyakit yang terjadi akibat tubuh manusia kekurangan air.

II. Ketika sisa zat makanan tidak dapat dikeluarkan dalam bentuk kotoran besar, akan mengalami sakit dan mual.

III. Ketika manusia kekurangan oksigen, akan mengalami sesak nafas dan mungkin akan mengantarkannya pada kematian.

Berdasarkan penjelasan di atas, kebutuhan jasmani 
merupakan kebutuhan organ tubuh manusia yang berkaitan dengan kadar tertentu yang telah ditetapkan oleh Allah Swt pada manusia. Kebutuhan jasmani ini adalah merupakan potensi kehidupan manusia.

b) Naluri

Syaikh Taqiyuddin anNabhani menjelaskan bahwa naluri adalah merupakan potensi kehidupan yang mendorong manusia untuk melakukan aktivitas-aktivitas tertentu, serta menuntut pemenuhan, namun sifatnya tidaklah harus. Ketika naluri ini tidak dipenuhi, maka tidak akan menyebabkan kerusakan organ tubuh dan tidak akan membawa kepada kematian. Artinya, jika kebutuhan naluri ini tidak terpenuhi, maka manusia tidak akan celaka dan tidak akan mati. Namun yang terjadi hanyalah rasa cemas dan galau. Perasaan cemas ini akan tetap mengganggu manusia sampai terpenuhinya naluri tersebut (An-Nabhani, 2001). Menurut Syaikh Taqiyuddin anNabhani naluri dalam diri manusia dapat digolongkan dalam tiga bentuk naluri yaitu, naluri mempertahankan diri (gharîzah al-baqo'), naluri melestarikan keturunan (gharîzah an-naw'), dan naluri mengagungkan sesuatu (gharîzah at-tadayyun) (An-Nabhani, 1973).

I. Naluri mempertahankan diri (Gharîzah al-baqo')

Gharîzah
adalah
mempertahankan diri (An-
nabluri
Nabhani, 2003), naluri ini
mendorong manusia untuk
berperilaku yang dapat
mempertahankan

eksistensinya sebagai

manusia atau individu. Naluri ini memiliki kecenderungan untuk mempertahankan dirinya sendiri, dan dorongan untuk menjaga dirinya sendiri, sebagai individu. Naluri ini mendorong manusia senantiasa berusaha untuk mempertahankan eksistensi dirinya, ketika manusia menghadapi segala sesuatu yang mengancam eksistensinya, pada dirinya akan segera muncul perasaan yang sesuai dengan jenis ancaman tersebut, manifestasimanifestasinya antara lain: rasa ingin tahu, senang meneliti, keinginan memiliki harta, ingin melaksanakan suatu aktivitas, mencintai kehormatan, keinginan untuk dipuja-puji, mementingkan diri sendiri, perasaan kikir, perasaan ingin menyendiri, perasaan marah, khawatir terjadi bahaya, perasaan takut, memerlukan rumah, perasaan ingin berkelompok, mencintai kekuasaan, mencintai kedaulatan, keberanian, keinginan untuk memimpin, mencintai kaumnya, dan lain sebagainya. Naluri ini mendorong manusia untuk berprilaku dalam memenuhi kebutuhannya.

II. Naluri Melestarikan Keturunan (Gharîzah annaw')

\begin{tabular}{lr}
\multicolumn{1}{c}{ Gharîzah } & an-nau' \\
adalah & naluri \\
mempertahankan & dan \\
melestarikan keturunan & (An-
\end{tabular}


Agus Silahudin; Perbandingan Konsep Kepribadian Menurut Barat Dan Islam.

Nabhani, 2001). Naluri ini melahirkan kecendrungan dan dorongan seksual. Adapun diantara indikasiindikasinya adalah kecenderuang seksual, rasa ingin mencintai dan dicintai, simpati, empati, sifat keayahan, sifat keibuan, rasa persaudaraan, dan seterusnya. Semua indikasiindikasi ini membantu manusia dalam meneruskan keturunan dan menjaga kelangsungan keturunan manusia. Disamping itu, naluri ini akan menimbulkan perasaan yang mendorongnya untuk berperilaku

III. Naluri Mengagungkan Sesuatu (Gharîzah attadayyun)

Gharîzah at-tadayyun adalah naluri beragama (An-Nabhani, 2003). Naluri inilah yang mendorong manusia untuk berperilaku yang mengagungkan atau mensucikan sesuatu. Naluri ini muncul karena perasaan manusia bahwa secara alamiah dirinya lemah, butuh yang lain, banyak kekurangan, dan kecenderungan kepada yang maha sempurna, yakni di sana ada kekuatan yang lebih besar dari dirinya. Perasaan lemah dalam diri manusia ini menimbulkan manifestasimanifestasinya antara lain, membutuhkan kepada yang lain, kagum dengan sistem alam semesta, mensucikan alam, mengagungkan orang-orang kuat, menghormati orang-orang

kuat, memuji

kepemimpinnya,

mengagungkan pahlawan, memohon pada Allah ketika ditimpa sengsara, perasaan ingin beribadah, rasa takut pada hari kiamat, berserah diri pada Allah Swt. Semua itu akan menimbulkan perasaan yang mendorongnya untuk berperilaku. Dalam pembentukan kepribadian fungsi nafsiyah adalah mengarahkan dorongandorongan kebutuhan jasmani dan naluri sesuai dengan mafahim yang dimilki oleh seseorang.

Demikianlah penjelasan tentang unsur-unsur pembentuk kepribadian yang terdapat dalam diri manusia. Namun unsur-unsur ini hanya dapat menghasilkan sebuah reaksi saja dan belum dapat menghasilkan sebuah kepribadian tertentu pada diri seseorang. Untuk membentuk sebuah kepribadian islami pada diri seseorang diperlukan unsur dari luar, yaitu sebuah informasi yang terdiri dari akidah dan tsaqofah atau ilmu pengetahuan. Informasi inilah yang akan menghukumi sebuah fakta/realitas yang ditemui oleh manusia dalam kehidupan dan dalam memenuhi kebutuhan jasmani dan naluri. Sehingga melahirkan sebuah pemahaman yang menjadi tolak ukur dalam melakukan perbuatan. Dengan demikian ketika akidah Islam dan tsaqofah Islam yang tersimpan didalam otak manusia sebagai informasi yang akan menghukumi fakta/realitas yang terindera dan dalam memenuhi kebutuhan jasmani dan naluri, maka 
akan terlahirlah pemahaman Islam yang melahirkan perbuatan islami. Dengan ini akan terbentuklah kepribadian islami.

b. Unsur-Unsur Pembentuk Kepribadian Islami dari Luar Diri Manusia

Unsur pembentuk kepribadian yang terdapat dari luar diri manusia adalah terdiri dari fakta/realitas dan informasi yang didapatkan oleh manusia sebagai ilmu pengetahuan yang terdiri dari akidah dan tsaqofah. Informasi ini tersimpan dalam otak manusia yang digunakan oleh akal untuk menghukumi fakta/realitas yang terindera dan sebagai landasan dalam memenuhi kebutuhan jasmani dan naluri. Kemudian unsusr-unsur ini dijelaskan sebagai berikut:

1) Fakta (Realitas)

Fakta didefinisikan sebagai segala sesuatu yang berada dalam jangkauan penginderaan manusia. Selain itu, fakta merupakan sesuatu yang menjadi objek pemikiran manusia, sebelum manusia mengeluarkan suatu keputusan atau kesimpulan mengenai objek tersebut. Fakta bisa saja berupa benda-benda fisik, seperti atom, planet, atau bahan kimia, dan bisa juga berupa ide atau konsep yang tidak bersifat fisik, seperti katakata, rumus dan persamaan matematika. Fakta dapat diindera oleh manusia, baik secara langsung maupun tidak langsung. Dalam kedua hal tersebut, sebuah fakta haruslah dapat dijangkau oleh akal manusia, dan fakta ini tentu dapat diindera oleh satu atau lebih alat indera (Abdurrahman, M. 2011).
Meskipun fakta atau realitas merupakan perkara penting dalam proses berfikir, akan tetapi penginderaan pada fakta boleh jadi tidak cukup memadai untuk memulai proses berfikir. Fakta harus dipelajari secara mendalam dengan penginderaan secara berulang-ulang dengan pengamatan yang sempurna sehingga menghasilakan kesimpulan yang akurat.

2) Informasi Awal (IImu Pengetahuan) Informasi awal adalah merupakan ilmu dan pengetahuan-pengetahuan yang diperoleh manusia yang tersimpan di dalam otaknya. Dalam pembentukan kepribadian islami informasi awal ini berupa akidah Islam dan pengetahuanpengetahuan yang terpancar dari akidah Islam yang berupa tsaqofah Islam.

a) Aqidah

Syaikh Taqiyuddin anNabhani, mendefinisikan akidah secara umum sebagai berikut:

"Aqidah adalah pemikiran yang menyeluruh tentang alam semesta, manusia dan kehidupan, tentang sebelum dan sesudah kehidupan dunia, serta hubungan ketiganya dengan sebelum dan sesudah kehidupan". (An-Nabhani, 2001) Adapun yang dimaksud dengan pemikiran yang menyeluruh, adalah pemikiran yang mendasar tentang alam semesta, manusia dan kehidupan, sebab ketiga hal inilah yang dapat terjangkau oleh indera manusia, dan dipahami oleh akalnya. Sedangkan yang dimaksud dengan sebelum dan sesudah kehidupan dunia, serta 
Agus Silahudin; Perbandingan Konsep Kepribadian Menurut Barat Dan Islam.

hubungan ketiganya dengan sebelum dan sesudah kehidupan, maksudnya adalah ada siapa sebelum kehidupan dunia ini dan akan kemana setelah kehidupan ini serta apa kaitannya dengan kehidupan di dunia ini. Semua ini merupakan interpretasi untuk pertanyaan-pertanyaan yang menyelimuti manusia, yaitu siapa yang menciptakan alam, manusia dan kehidupan ini? untuk apa alam, manusia dan kehidupan ini diciptakan? dan akan kemana manusia setelah kehidupan ini berakhir?

Menurut Syaikh Taqiyuddin an-Nabhani ketiga pertanyaan di atas adalah merupakan pertanyaan mendasar dalam diri manusia, sehingga jawaban dari ketiga pertanyaan tersebut melahirkan sebuah akidah. Dalam hal ini Syaikh Taqiyuddin anNabhani menggolongkan akidah terbagi menjadi tiga. Sebagaimana dijelaskan berikut ini:

I. Akidah Islam

Aqidah Islam adalah akidah yang mengimani, bahwa di balik alam semesta, manusia dan kehidupan ada pencipta yang telah menciptakannya, dan yang menciptakan segala sesuatu, yaitu Allah Swt. Ini merupakan jawaban atas pertanyaanpertanyaan manusia tentang sebelum kehidupan dunia ini. Kemudian aqidah Islam menjelaskan tentang sesudah kehidupan dunia ada hari akhirat, hisab, surga dan neraka. Adapun hubungannya dengan sebelum kehidupan dunia adalah eksistensi kehidupan sebagai makhluk ciptaan Allah Swt, yang diperintahkan untuk beribadah dan terikat dengan aturan Allah Swt. Adapun hubungan kehidupan dengan sesudahnya adalah adanya hisab atas apa yang telah dilakukan manusia didalam kehidupannya.

Berdasarkan keyakinan seperti ini, maka manusia harus terikat dengan aturan Allah Swt, dalam kehidupan di dunia ini. Karena itu, manusia wajib berjalan dalam kehidupan ini sesuai dengan peraturan Allah, dan wajib meyakini bahwa ia akan di hisab di hari kiamat nanti atas seluruh perbuatan yang dilakukannya di dunia. Dengan keyakinan seperti ini maka tertanamlah aqidah Islam pada diri seseorang. Sehingga seorang muslim yang menyakini akidah Islam harus mengetahui hubungan dirinya dengan Allah pada saat melakukan perbuatan, sehingga seluruh perbuatan mengikuti perintah-perintah Allah dan menjauhi laranganlarangan Allah. Di samping itu, tujuan akhir dari kepatuhannya terhadap perintah-perintah dan larangan-larangan Allah adalah mendapatkan ridha Allah semata. (An-Nabhani, 2001)

II. Aqidah Sekuler

Akidah sekuler adalah aqidah yang memisahkan agama dari kehidupan. Mereka mengakui adanya pencipta alam semesta, manusia, dan hidup, serta mengakui adanya hari kebangkitan. Sebab, semua itu adalah dasar pokok agama, ditinjau dari 
keberadaan suatu agama. Dengan pengakuan ini berarti terdapat ide tentang alam semesta, manusia, dan hidup, serta apa yang ada sebelum dan sesudah kehidupan dunia, sebab mereka tidak menolak keberadaan agama. Namun tatkala ditetapkan bahwa agama harus dipisahkan dari kehidupan, maka pengakuan itu akhirnya hanya sekadar formalitas belaka, karena sekalipun mereka mengakui keberadaannya, tetapi pada dasarnya mereka menganggap bahwa kehidupan dunia ini tidak ada hubungannya dengan apa yang ada sebelum dan sesudah kehidupan dunia. Anggapan ini muncul ketika dinyatakan adanya pemisahan agama dari kehidupan, dan bahwasanya agama hanya sekedar hubungan antara individu dengan penciptanya saja (An-Nabhani, 2001). Dengan demikian, akidah ini menjawab pertanyaan ketiga di atas tadi, bahwa manusia, alam dan kehidupan berasal dari Allah. Hidup didunia memisahkan antara kehidupan dengan agama, yang mana agama hanya untuk urusan spiritul belaka. Kemudian mati kembali kepada Allah.

III. Akidah Komunis Akidah komunisme adalah akidah yang mengimani bahwa alam semesta, manusia, dan hidup adalah materi. Bahwa materi adalah asal dari segala sesuatu. Melalui perkembangan dan evolusi materi benda-benda lainnya menjadi ada. Di balik alam materi tidak ada alam lainnya. Materi bersifat azali (tak berawal dan tak berakhir), qadim (terdahulu) dan tidak ada yang mengadakannya. Dengan kata lain bersifat wajibul wujud (wajib adanya). Penganut akidah ini mengingkari penciptaan alam oleh Zat yang maha pencipta. Mereka mengingkari aspek kerohanian, dan beranggapan bahwa pengakuan adanya aspek rohani merupakan sesuatu yang berbahaya bagi kehidupan. Agama dianggap sebagai candu yang meracuni masyarakat dan menghambat pekerjaan. Bagi mereka tidak ada sesuatu yang berwujud kecuali hanya materi, bahkan menurutnya, berpikir pun merupakan refleksi materi ke dalam otak. Materi adalah pangkal berpikir dan pangkal dari segala sesuatu, yang berproses dan berkembang dengan sendirinya lalu mewujudkan segala sesuatu. Ini berarti mereka mengingkari adanya sang pencipta (alKhaliq) dan menganggap materi itu bersifat azali, serta mengingkari adanya sesuatu sebelum dan sesudah kehidupan dunia dan yang mereka akui hanya kehidupan dunia ini saja (An-Nabhani, 2001).

Dengan demikian, akidah komunisme menjawab tiga pertanyaan diatas, bahwa manusia, alam dan kehidupan berasal dari materi ada dengan sendirinya. Kehidupan hidup di dunia ini untuk memuaskan materi dan mati kembali ke materi.

b) Tsaqofah 
Agus Silahudin; Perbandingan Konsep Kepribadian Menurut Barat Dan Islam.

Tsaqofah

secara

terminologis adalah, pengetahuan yang diambil melalui berita-berita, talaqqiy (pertemuan secara langsung) dan instinbath (penggalian/penarikan

kesimpulan). Misalnya, sejarah, bahasa, fikih, filsafat, ekonomi, politik, pendidikan dan seluruh pengetahuan non eksperimental lainnya (An-Nabhani, 2001). Tsaqofah mencakup akidah dan segala sesuatu yang terpancar dari akidah, baik itu berupa hukum, sistem, dan berbagai cabang ilmu pengetahuan (Yasin. A, 2004). Dengan demikian tsaqofah adalah sekumpulan pengetahuan yang mempengaruhi akal dan sikap seseorang terhadap fakta (benda maupun perbuatan), seperti masalah hukum, ekonomi, sejarah dan lain sebagainya. Tsaqofah adalah pemikiranpemikiran yang menjelaskan sudut pandang dalam kehidupan. Pemikiran-pemikiran inilah yang membentuk sebuah mafahim yang mengantarkan terciptanya sebuah perbuatan. Berdasarkan hal ini, tsaqofah Islam berbeda dengan tsaqofah kapitalis, dan tsaqofah sosialis. Dengan ini tsaqofah dapat digolongkan menjadi dua, yakni tsaqofah Islam dan tsaqofah asing (kapitalis dan sosialis) sesuai dengan akidah yang dijadikan landasan dalam pembahasannya.

\section{Tsaqofah Islam}

Tsaqofah Islam adalah pengetahuan-pengetahuan

yang menjadikan aqidah Islam sebagai landasan dalam pembahasannya (Yasin. A, 2004). Tsaqofah Islam ini terpancar dari akidah Islam, yakni berbagai pengetahuan yang mengandung aqidah Islam dan membahas tentang aqidah, seperti ilmu tauhid. Bisa juga pengetahuan yang bertumpu kepada aqidah Islam, seperti fiqih, tafsir dan hadits. Termasuk ilmu pengetahuan yang terkait dengan pemahaman yang terpancar dari aqidah Islam berupa hukum-hukum, ilmuilmu bahasa Arab, musthalah hadits, ilmu ushul, sistem ekonomi Islam, sistem politik Islam, sistem sosial Islam dan sistem pendidikan Islam. Semuanya termasuk tsaqafah Islam, karena aqidah Islam menjadi landasan dalam pembahasannya.

II. Tsaqofah Asing (Kapitalis dan Sosialis)

Tsaqofah asing adalah tsaqofah yang bukan dari Islam dan pembahasannya tidak berlandaskan akidah Islam, yakni berlandaskan akidah selain dari Islam. Tsaqofah asing berupa ilmu pengetahuan yang terpancar dari akidah yang bukan Islam dan akidah tersebut manjadi dasar dan landasan dalam pembahasannya. Sehingga melahirkan ilmu pengetahuan berupa sistem ekonomi, sistem politik, sistem pendidikan, sistem sosial dan berbagai pengetahuan lain.

Berdasarkan penjelasan di atas, berkenaan dengan unsur-unsur pembentuk kepribadian manusia, baik unsur dari dalam diri manusia maupun unsur diluar diri manusia. Kepribadian manusia terbentuk dari gabungan 
unsur-unsur dalam diri manusia dan unsur dari luar diri manusia. Unsur dari luar diri manusia yang berupa fakta/realitas dan informasi awal yang tersimpan dalam otak manusia inilah yang membentuk kepribadian seseorang. Dengan demikian perbedaan akidah dan tsaqofah yang menjadi landasan dalam berfikir untuk menghukumi fakta/realitas akan mempengaruhi kesimpulan atau pemahaman yang berbeda terhadap fakta/realitas yang terindera, sehingga melahirkan perbuatan yang berbeda-beda pula. Ketika landasan yang digunakan dalam menghukumi fakta/realitas bersumber dari akidah Islam dan tsaqofah Islam, maka proses berfikirnya akan dibangun berdasarkan akidah dan tsaqofah tersebut. Dengan ini akan terbangun pemahaman Islam yang akan mempengaruhi dalam pemenuhan kebutuhan jasmani dan nalurinya, sehingga akan muncul perbuatan yang sesuai dengan akidah Islam. Namun ketika informasi atau pengetahuan tersebut bersumber dari akidah dan tsaqofah kapitalis, maka proses berfikirnya akan dibangun berdasarkan akidah dan tsaqofah tersebut. Dengan ini akan terbangun pemahaman kapitalis yang akan mempengaruhi dalam pemenuhan kebutuhan jasmani dan nalurinya, sehingga akan muncul perbuatan yang sesuai dengan akidah dan tsaqofah tersebut, yakni memisahkan antara kehidupan dengan agama. Demikian juga halnya ketika yang dijadikan landasan dalam proses berfikir dan pemenuhan kebutuhan jasmani dan nalurinya adalah akidah dan tsaqofah sosialis komunis. Dengan demikian, yang menentukan perbuatan seseorang dalam memenuhi kebutuhan jasmani dan nalurinya adalah landasan yang dijadikan tolak ukur dalam proses berfikir. Berdasarkan hal ini, pembentukan kepribadian islami pada seseorang dapat dibentuk dengan akidah dan tsaqofah Islam.

Inilah unsur-unsur pembentuk kepribadian islami menurut Syaikh Taqiyuddin anNabhani dan inilah konsep terhadap unsur pembentuk kepribadian islami. Pandangan Syaikh Taqiyuddin an-Nabhani tentang unsur-unsur pembentuk kepribadian manusia ini berbeda dengan konsep dan pandangan psikologi barat, terutama tentang konsep otak dan naluri.

Menurut Syaikh Taqiyuddin an-Nabhani, pandangan ilmu psikologi barat yang menganggap bahwa otak dibagi kedalam beberapa bagian (otak kanan, otak kiri) dan setiap bagian memiliki potensi kemampuan khusus serta pada bagian otak tertentu ada potensi yang berbeda dengan yang ada di bagian otak lainnya adalah pandangan yang keliru. Karena pada kenyataannya 
Agus Silahudin; Perbandingan Konsep Kepribadian Menurut Barat Dan Islam.

otak itu hanya satu. Terjadinya keragaman serta perbedaan pemikiran yang dihasilkan adalah sebagai akibat beragam dan berbedanya fakta yang terindera serta informasi awal yang diterima. Jadi, di dalam otak tidak ditemukan adanya potensi yang tidak ditemukan di otak yang lain, tetapi keseluruhan otak memiliki potensi untuk berpikir dalam segala hal manakala terpenuhi empat hal yaitu fakta yang terindera, panca indera, informasiinformasi sebelumnya dan otak. Keragaman otak manusia hanya terjadi pada kekuatan mengingat dan mengindera, seperti halnya keragaman mata terjadi dalam aspek kuat dan lemahnya memandang. Dengan demikian, setiap orang bisa diberi informasi apa saja dan dalam dirinya memiliki potensi untuk mengolah berbagai informasi yang masuk. Karena itu, anggapan ilmu psikologi barat yang mengatakan otak memiliki bagian-bagian dan setiap bagian memiliki potensipotensi yang berbeda-beda sama sekali tidak memiliki dasar (An-Nabhani, Taqiyuddin, 2002).

Sedangkan tentang konsep naluri, menurut Syaikh Taqiyuddin an-Nabhani pandangan para ahli psikologi barat yang mengatakan bahwa naluri itu banyak sekali macamnya, ada yang dapat disingkap ada pula yang tidak adalah keliru. Sebab, dalam pandangan an-Nabhani bahwa potensi kehidupan manusia, yang berupa naluri-naluri itu tergabung dalam tiga kelompok, yaitu: naluri beragama, naluri melangsungkan keturunan, dan naluri mempertahankan diri. Ini, artinya bahwa setiap yang disebut dengan naluri, maka dikembalikan kedalam salah satu dari tiga kelompok tersebut, sebab ia merupakan indikasi naluri, bukan naluri yang berdiri sendiri (AnNabhani, Taqiyuddin, 2002). Dengan demikian menurut Syaikh Taqiyuddin anNabhani pandangan ilmuan psikologi barat tentang konsep kepribadian manusia, dalam hal ini teori tentang otak dan naluri adalah keliru. Inilah bantahan Syaikh Taqiyuddin an-Nabhani terhadap psikologi barat yang merupakan tsaqofah asing.

\section{KESIMPULAN}

Menurut Syaikh Taqiyuddin AnNabhani, kepribadian manusia tidak ada kaitannya dengan bentuk tubuh, wajah, keserasian fisik dan hal lain sejenisnya. Manusia memiliki keistimewaan disebabkan akalnya, sementara baik atau buruknya kepribadian manusia ditunjukkan oleh perbuatannya. Perbuatan adalah aktifitas yang dilakukan manusia dalam rangka memenuhi kebutuhan jasmani dan nalurinya. Perbuatan manusia terkait erat dengan mafahimnya serta tidak bisa dipisahkan. Sedangkan mafahim adalah pemahaman terhadap fakta/realitas berdasarkan landasan tertentu yang diyakini sebagai informasi yang tersimpan di dalam otak. Adapun aktifitas pemenuhan kebutuhan jasmani dan naluri 
berdasarkan mafahim yang dimiliki oleh seseorang disebut dengan pola sikap atau nafsiyah. Sedangkan aktifitas menghukumi fakta berdasarkan landasan tertentu yang diyakini disebut dengan pola berpikir atau aqliyah.

\section{Berdasarkan}

konsep

kepribadian di atas, kepribadian didefinisikan sebagai "satu kesatuan integrasi dari cara kerja aqliyah dan nafsiyah berdasarkan akidah tertentu yang diyakini kemudian melahirkan perbuatan". Definisi ini bersifat umum untuk seluruh definisi kepribadian manusia. Inilah definisi kepribadian dan inilah konsep kepribadian menurut Syaikh Taqiyuddin an-Nabhani.

Islam telah memberikan solusi terhadap manusia dalam mewujudkan kepribadian islami, yaitu dengan menjadikan akidah Islam sebagai landasan berfikir, yang diatas landasan tersebut dibangun seluruh pemikirannya serta dibentuk pemahamannya dalam memberikan solusi atas perbuatanperbuatan manusia yang timbul dari kebutuhan jasmani dan nalurinya dengan hukum-hukum syara' yang terpancar dari akidah tersebut. Dengan demikian setiap orang yang berpikir berdasarkan akidah Islam dan hawa nafsunya dikembalikan kepada akidah Islam maka seseorang tersebut memiliki kepribadian islami. Ketika akidah Islam yang dijadikan satu-satunya tolak ukur umum terhadap seluruh pemikiran dalam menghukumi fakta, maka terbangunlah pemahaman islami yaitu aqliyah Islam. Dan ketika akidah Islam yang dijadikan satusatunya tolak ukur umum dalam pemenuhan dorongan kebutuhan jasmani dan nalurinya secara praktis dan riil, maka terbangunlah pola sikap islami yaitu nafsiyah Islam. Dengan demikian, ketika seluruh perbuatan seseorang dibangun berdasarkan aqliyah Islam dan nafsiyah Islam maka terwujudlah kepribadian islami, yaitu kepribadian yang memiliki ciri khas Islam. Berdasarkan hal ini, kepribadian islami didefinisikan sebagai, "satu kesatuan integrasi dari cara kerja aqliyah dan nafsiyah berlandaskan akidah Islam yang melahirkan perbuatan". Inilah definisi dan konsep kepribadian islami menurut pandangan Syaikh Taqiyuddin anNabhani.

Unsur kepribadian manusia terdiri dari, unsur dalam diri manusia dan unsur diluar diri manusia. Unsur dalam diri manusia meliputi, panca indera, otak, akal dan nafsiyah. Namun keempat unsur ini hanya dapat menghasilkan reaksi saja. Oleh karena itu untuk dapat melahirkan sebuah perbuatan tertentu pada diri seseorang, dibutuhkan unsur dari luar diri manusia berupa fakta/realitas dan informasi awal yang tersimpan didalam otak manusia yang meliputi ilmu dan pengetahuan-pengetahuan yang terpancar dari akidah. Adapun informasi atau pengetahuan yang dijadikan landasan berfikir dalam menghukumi fakta/realitas oleh seseorang menurut Syaikh Taqiyuddin an-Nabhani, bersumber dari akidah Islam, akidah sekuler dan akidah komunis. Dari akidah inilah terpancar pengetahuanpengatuan yang berupa tsaqofah. Dengan demikian ketika ingin membentuk kepribadian islami pada seseorang maka harus menjadikan akidah Islam dan tsaqofah Islam sebagai landasannya.

\section{DAFTAR PUSTAKA}


Agus Silahudin; Perbandingan Konsep Kepribadian Menurut Barat Dan Islam.

Al-Qur'an, Kementrian Agama RI. 2010. Syaamil Qur'an, Kementrian Agama RI.

Abdurrahman Hafiz.. 2007.

Diskursus Islam Politik dan

Spiritual. Bogor: al-Azhar Press.

Abdul Mujib. 1999. Fitrah dan Kepribadian Islam, Jakarta: Darul Fatah.

2017. Kepribadian dalam Psikologi Islam, Jakarta: PT. Grafindo Persada.

Abdurrahman, $\quad$ M. 2011. Membangun Pemikiran Cemerlang, Cet, ke-2, Bogor: Pustaka Thariqul Izzah.

Adz-Dzakiey, Hamdani Bakran. 2006. Psikologi Kenabian, Yogyakarta: Daristy.

Ahyadi Abdul Aziz. 1987. Psikologi Agama, Bandung: Sinar Baru.

An-Nabhani, Taqiyuddin. 2002. AdDaulatul al-Islamiyah, Cet. ke7, Libanon: Dar al-Ummah.

2001.

Nizham al-Islam, Jakarta: Min Mansurati Hizbut Tahrir.

2003. asy-

Syakhshiyyah al-Islamiyyah, Cet. ke-VI, Libanon: Dar alUmmah.

2003. An-

Nizham Al-ljtima'i fi Al-Islam, Cet. ke-IV, Jakarta: Min Mansurati Hizbut Tahrir.

1973. atTafkir, Libanon: Min Mansurati Hizbut Tahrir.

An-Nawawi, Muhammad. 1990. alJawi, Syarh Kasifah asSaja'ala Safinah an-Naja. Semarang: Toha Putra.

Hamzah Ahmad dan Nanda Santoso. 1996. Kamus Pintar Bahasa Indonesia, Surabaya: Fajar Mulya.
Husen, Abdullah Muhammad. 2000. Studi Dasar-Dasar Pemikiran Islam, Cet, ke-V, Bogor: Pustaka Thariqul Izzah,

Lawrence A. Parwin, Psikologi Kepribadian Teori dan Penelitian, Jakarta: Prenadamedia Group, 2015.

Muhsin Rodhi, Muhammad. 2012. Tsaqofah dan Metode Hizbut Tahrir dalam Mendirikan Negara Khilafah, Bogor: alAzhar Fresh Zone.

Purwanto Yadi. 2007. Psikologi Kepribadian, Bandung: Refika Aditama.

Sumadi Suryabrata. 1993. Psikologi Kepribadian, Jakarta: Raja Grafindo Persada.

Sanapiah Faisol. 1995. Formatformat Penelitian, Bandung: PT. Raja Grafindo Persada.

Yasin, Abu. 2004. Usus at-Ta'lim fi Daulah al-Khilafah, Dar alUmmah. 